\title{
Applicability of Bromilow's Time-cost Model for Residential Projects in Slovakia
}

\author{
Daniela Mačková, Renáta Bašková \\ Technical University of Košice \\ Civil Engineering Faculty, Institute of Construction Technology and Management \\ e-mail: daniela.mackova@tuke.sk, renata.baskova@tuke.sk
}

\begin{abstract}
The concept of construction time has been mentioned by most researchers as one of the key factors of a successful project. Time-cost model for rapid estimation of construction time appeared in the world some fifty years ago and the most mentioned is model developed by Bromilow. The purpose of submitted research is to validate Bromilow's time-cost (BTC) model and identify constants in BTC model in context with residential construction projects in Slovak construction conditions. The data for the study were obtained from 28 residential projects completed within the period 2010-2013 in regions of Slovakia. The data were analyzed using classical correlation and regression analysis.
\end{abstract}

Key words: Bromilow's time-cost (BTC) model, construction time, construction cost

\section{Introduction}

Contract time overrun is a common problem in the construction industry. Construction delays emanate from a diversity of origins including contractor's faults, changes in design, other unforeseen events such as inclement weather and industrial relations disputes or just simply an overly optimistic predetermined contract duration [1]. Accurate estimate of construction time and cost is very important in negotiating contract terms. In the construction industry, contractors usually use previous experiences to estimate the project duration of a new project[3]. It would be very beneficial if there were reliable models of dependence for the factors of construction to facilitate estimation of construction time. The first model of timecost dependency was conducted in Australia by Bromilow in 1969. It is called Bromilow's time-cost (BTC) model and it enables the construction period to be calculated according to the estimated final cost of a project. This model was since year 1969 validated and adapted to the construction conditions of other countries by researchers from these countries. The purpose of submitted study is to validate Bromilow's time-cost model and identify constants in BTC model in context with residential construction projects in Slovak construction conditions. It 
does not incorporate the implications of other factors that are likely to influence the total time required for the completion of a construction projects.

\section{Theoretical background}

Bromilow's study in 1969 revealed that the time taken to construct a project is highly correlated with the size as measured by cost. Construction time in working days could be expressed as a function of cost based on the exponentional curve of best fit and upper and lower quartile limits derived from the historical data [1]. On this basis Bromilow's time-cost model was defined by formula 1 :

$$
T=K * C^{B}
$$

where $T=$ construction time (in days),

$C=$ estimated cost of project (in million dollar),

$K=$ a constant describing the general level of time performance,

$B=a$ constant describing how the time performance was affected by project size as measured by cost.

The constants $K$ and $B$ may vary depending on the construction conditions of the country, but also depending on the construction sector. As already mentioned BTC model was several times validated and adapted for different countries by many researchers $[1,3,6,7]$. Some of them are summarized in Table $1[5,6,7]$.

Table 1: $K$ and B values for some BTC models

\begin{tabular}{|c|c|c|c|c|c|c|}
\hline Researcher & Year & Country & $\begin{array}{l}\text { Construction } \\
\text { segment }\end{array}$ & Unit of measure & $\bar{K}$ & $\mathbf{B}$ \\
\hline \multirow[t]{3}{*}{ Bromilow } & \multirow[t]{3}{*}{1969} & \multirow[t]{3}{*}{ Australia } & Public projects & \multirow[t]{3}{*}{ million dollar } & 211 & 0,30 \\
\hline & & & Private projects & & 156 & 0,30 \\
\hline & & & Overall projects & & 177 & 0,30 \\
\hline Bromilow & 1974 & Australia & Overall projects & million dollar & 313 & 0,30 \\
\hline Ireland & 1983 & Australia & Overall projects & million dollar & 155 & 0,47 \\
\hline Ireland & 1985 & Australia & High-rise buildings & million dollar & 219 & 0,47 \\
\hline \multirow[t]{3}{*}{ Bromilow } & \multirow[t]{3}{*}{1988} & \multirow[t]{3}{*}{ Australia } & Public projects & \multirow[t]{3}{*}{ million dollar } & 186 & 0,38 \\
\hline & & & Private projects & & 136 & 0,28 \\
\hline & & & Overall projects & & 164 & 0,30 \\
\hline \multirow{2}{*}{$\begin{array}{l}\text { Kaka and } \\
\text { Price }\end{array}$} & \multirow[t]{2}{*}{1991} & United & Public projects & \multirow[t]{2}{*}{-} & 398 & 0,32 \\
\hline & & Kingdom & Private projects & & 274 & 0,21 \\
\hline \multirow[t]{2}{*}{ Yeong } & \multirow[t]{2}{*}{1994} & Australia & Overall projects & \multirow[t]{2}{*}{ million dollar } & 269 & 0,21 \\
\hline & & Malajzia & Public projects & & 518 & 0,35 \\
\hline \multirow{2}{*}{$\begin{array}{l}\text { Kumaraswamy } \\
\text { and Chan }\end{array}$} & \multirow[t]{2}{*}{1995} & \multirow[t]{2}{*}{ Hong Kong } & Public projects & \multirow[t]{2}{*}{-} & 188 & 0,26 \\
\hline & & & Private projects & & 160 & 0,31 \\
\hline \multirow{3}{*}{$\begin{array}{l}\text { Ng, Mak, } \\
\text { Skitmore, } \\
\text { Varnam }\end{array}$} & \multirow[t]{3}{*}{1998} & \multirow[t]{3}{*}{ Australia } & Public projects & \multirow[t]{3}{*}{ million dollar } & 129 & 0,32 \\
\hline & & & Private projects & & 132 & 0,30 \\
\hline & & & Overall projects & & 131 & 0,31 \\
\hline \multirow[t]{3}{*}{ Chan } & \multirow[t]{3}{*}{1999} & \multirow[t]{3}{*}{ Hong Kong } & Public projects & \multirow[t]{3}{*}{-} & 166 & 0,28 \\
\hline & & & Private projects & & 120 & 0,34 \\
\hline & & & Overall projects & & 152 & 0,29 \\
\hline Chan & 2001 & Malajzia & Overall projects & - & 269 & 0,34 \\
\hline $\begin{array}{l}\text { Choudhury et } \\
\text { al }\end{array}$ & 2002 & Bangladesh & Health sector & - & 5 & 0,27 \\
\hline
\end{tabular}




\begin{tabular}{lllllll}
$\begin{array}{l}\text { Choudhury } \\
\text { and Rajan }\end{array}$ & 2003 & Texas, USA & $\begin{array}{l}\text { Residential } \\
\text { construction }\end{array}$ & thousand dollar & 19 & 0,39 \\
$\begin{array}{l}\text { Czarnigowska } \\
\text { and Sobotka }\end{array}$ & 2009 & Poland & Road & $\begin{array}{l}\text { thousand polish } \\
\text { zloty }\end{array}$ & 3,46 \\
$\begin{array}{l}\text { Žujo, Car- } \\
\begin{array}{l}\text { Pušić } \\
\hline\end{array}\end{array}$ & 2009 & Bosnia and & New construction & 100 thousand & 70 & 0,52 \\
\hline
\end{tabular}

However, the results of some studies show that the relationship between construction time and construction cost showed very little correlation coefficient. Based on this, we can argue, that the formula 1 is not applicable in some construction conditions in some countries [2], [4].

The task of this research is to determine degree of dependence (correlation coefficient) between time and cost for residential projects in Slovakia. If the correlation coefficient is high we can also determine constants in BTC model for residential projects in Slovak construction conditions.

\section{Research methodology}

Primary data of 28 residential projects were collected from different regions of Slovakia. Information obtained in respect of each project included: project type, construction site, final construction cost, commencement date, completion date. The data were limited to comparable projects completed within the period from 2010 to 2013. This is because the period was considered to have experienced almost the same economic climate. Construction time and cost details of the residential projects surveyed are shown in Table 2.

Table 2: Construction time and cost of the residential projects

\begin{tabular}{cccccc}
\hline $\begin{array}{l}\text { Project } \\
\text { no. }\end{array}$ & $\begin{array}{l}\text { Construction } \\
\text { cost (in mil. } \boldsymbol{€})\end{array}$ & $\begin{array}{l}\text { Construction } \\
\text { time (in days) }\end{array}$ & $\begin{array}{l}\text { Project } \\
\text { no. }\end{array}$ & $\begin{array}{l}\text { Construction } \\
\text { cost (in mil. } \boldsymbol{€} \text { ) }\end{array}$ & $\begin{array}{l}\text { Construction } \\
\text { time (in days) }\end{array}$ \\
\hline 1 & 1,8 & 480 & 15 & 55,0 & 1410 \\
2 & 2,5 & 600 & 16 & 4,5 & 630 \\
3 & 3,5 & 480 & 17 & 97,0 & 1530 \\
4 & 1,7 & 360 & 18 & 32,4 & 840 \\
5 & 1,8 & 540 & 19 & 14,0 & 780 \\
6 & 2,0 & 480 & 20 & 2,7 & 480 \\
7 & 2,7 & 450 & 21 & 6,4 & 570 \\
8 & 3,0 & 570 & 22 & 3,8 & 690 \\
9 & 6,4 & 720 & 23 & 4,2 & 450 \\
10 & 2,8 & 420 & 24 & 21,5 & 840 \\
11 & 4,8 & 480 & 25 & 9,0 & 630 \\
12 & 1,4 & 480 & 26 & 9,6 & 780 \\
13 & 2,8 & 360 & 27 & 100,0 & 900 \\
14 & 6,4 & 780 & 28 & 31,5 & 1080 \\
\hline
\end{tabular}

Graphical tool - scatter plot was used on initial examination of the selected parameters relationship. The data is displayed as a collection of points, each having the value of one variable determining the position on the horizontal " $x$ " axis and the value of the other variable 
determining the position on the vertical "y" axis. Scatter plot was made in software Excel, where on the " $x$ " axis there are values of construction cost in million euro and on the " $y$ " axis there are values of construction time in days (Figure 1). We can see, that between construction cost and construction time, there is a relationship that can be described by the exponentional curve.

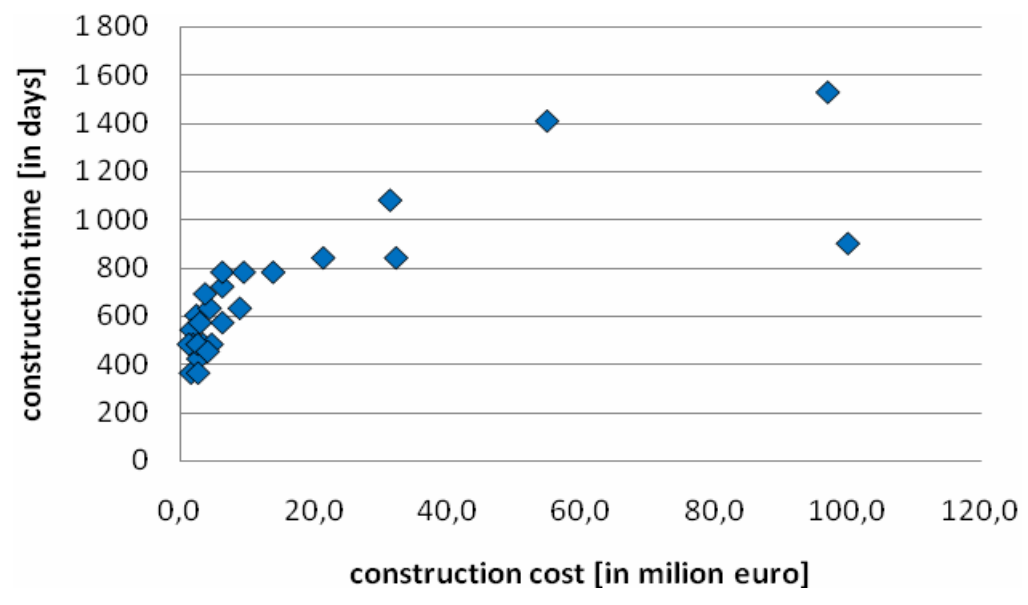

Figure 1: Scatter plot of the origin data

It is evident (of Figure 1) that there is not a linear relationship between construction time and construction cost, hence it is necessary model transformation for further statistical analysis. Based on the theoretical knowledge that the time-cost relationship is defined by the origin Bromilow model (1), it was transformed by natural logarithms to the linearized form as follows:

$$
\ln T=\ln K+B * \ln C
$$

where $\quad \ln T=$ natural logarithm of time,

$\ln K=$ natural logarithm of $K$,

$B=$ coefficient of $\ln C$, and

$\ln C=$ natural logarithm of cost.

Subsequently classical linear regression and correlation technique was used to analyze the linearized model.

\section{Results and interpretations}

Pearson correlation coefficient values of 0.8816 points the high degree of dependency between natural logarithm of time and natural logarithm of cost. Correlation is significant at the 0.05 level (2-tailed).

The final linear regression model, where dependent variable is natural logarithm of time and independent variable is natural logarithm of cost, has the high coefficient of determination and adjusted coefficient of determination values of 0.776 and 0.768 , respectively. It is shown 
that over 76 percent of the variance in natural logarithm of time estimation can be explained by natural logarithm of cost. This regression model is statistically significant at the 0.05 level. It has been considered very good in terms of goodness of fit. It can therefore be concluded that the time-cost relationship for the residential projects in Slovakia can be expressed using the model defined by formula 1 developed by Bromilow. However, it is still necessary to determine constants $\mathrm{K}$ and $\mathrm{B}$ in the BTC model.

The aim of the classical linear regression analysis is also to determine the coefficients for regression function (coefficients $\mathrm{B}_{0}$ a $\mathrm{B}_{1}$ ) in form:

$$
Y=B_{0}+B_{1} * X
$$

where $\quad B_{0}-$ constant that expresses the expected level of regression function at zero value of the independent variable,

$B_{1}$ - regression coefficient, which expresses the amount of units of dependent variable " $Y$ " changes when the independent variable " $X$ " will change the one unit of measure.

Regression coefficients for transformed model were defined as $\mathrm{B}_{0}=5.951, \mathrm{~B}_{1}=0.263$ and regression function in form:

$$
Y=5.961+0.263 * X
$$

Based on the formula 2 and formula 4 it can be concluded that constants $\mathrm{K}$ and $\mathrm{B}$ for Bromilow's relationship for residential projects in Slovakia were defined:

$$
\begin{aligned}
& \ln T=Y, \\
& \ln K=B_{0}=5.951, \\
& \mathbf{B}=B_{1}=\mathbf{0 . 2 6 3}, \\
& \ln C=X .
\end{aligned}
$$

The value of $\ln K$ is required to be transformed to $K$, using an exponential function as we can see in formula 5.

$$
\mathbf{K}=e^{5.951}=\mathbf{3 8 4}
$$

Bromilow's time-cost model in context with residential construction projects in Slovak construction conditions then we can adopt in the form:

$$
\mathbf{T}=\mathbf{3 8 4} * C^{0,263}
$$

where

$$
\begin{aligned}
& T=\text { construction time (in days), } \\
& C=\text { estimated cost of project (in million euro). }
\end{aligned}
$$

The results of the study indicate that for a residential construction project in Slovak construction conditions, an increase in the estimated cost results in an increase in the construction time. It is found that for a residential project worth us one million euro, the construction time is 384 days for the project completion.

Time-cost model for construction time estimation (formula 6) was created by statistical analysis of the real data (Table 2). Scatter plot was created from that data (Figure 1) and point which represents residential project number 27 (with position data 100; 900) appears to be 
extreme. Because of this, it was necessary to exclude this project from the data set and to verify the extreme value impact on the resulting model.

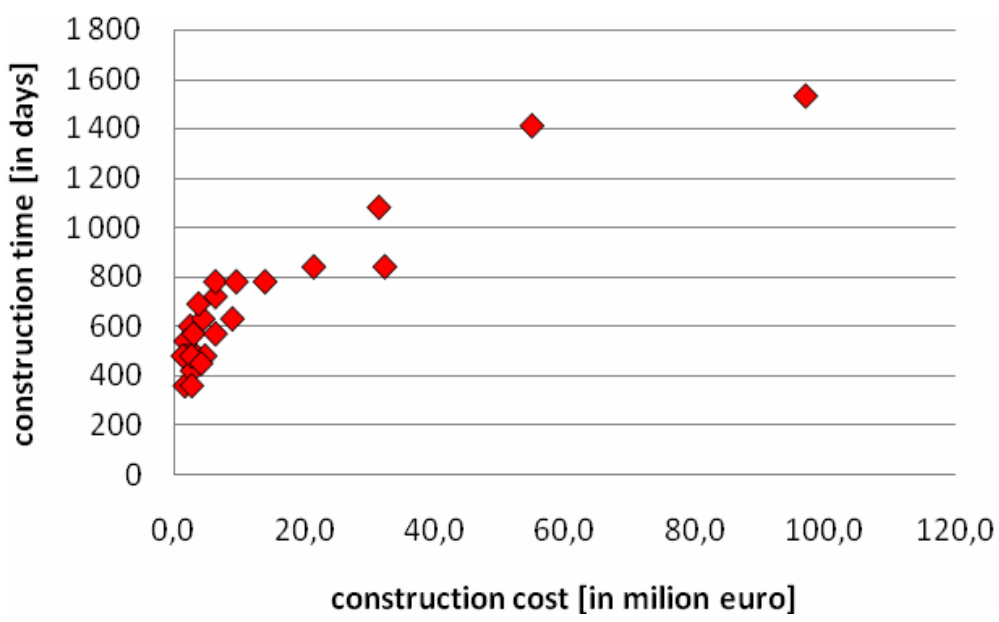

Figure 2: Scatter plot of the adapted data

Adapted set of data (Figure 2) was analyzed by classical linear regression and correlation technique and another time-cost model for construction time estimation was defined:

$$
\mathbf{T}=\mathbf{3 8 6} * C^{0,295}
$$

where $\quad T=$ construction time (in days),

$C=$ estimated cost of project (in million euro).

Based on the model (formula 7) it was found that for a residential project worth us one million euro, the construction time is 368 days for the project completion.

Then, curves for both models (formulas 6,7) were created and compared (Figure 3).

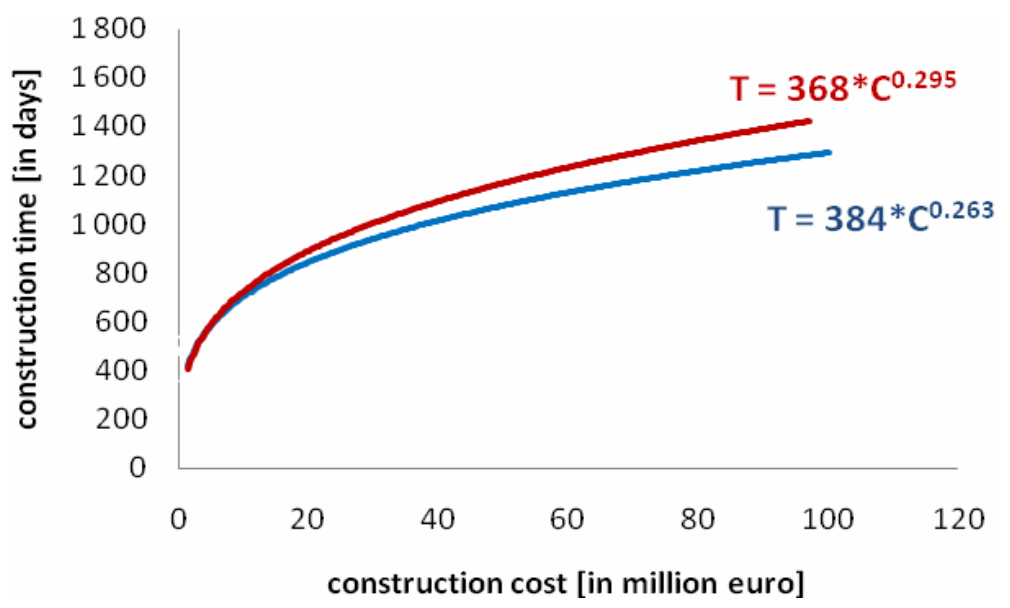

Figure 3: Two time-cost models (formulas 6,7 ) and their comparison 
From Figure 3 it is evident that there is a little difference in the construction time estimation using the formula 6 and formula 7 for the project which construction cost is under 20 million euro, and therefore, it is possible to estimate the construction time using one of the models. For project with projected construction cost is over 20 million euro, it is appropriate to estimate construction time by both models and thus define the interval of construction time estimation.

Subsequently model defined by formula 6 and model defined by formula 7 were tested on new database with the total of 7 residential projects (Table 3) and results are estimated as satisfactory.

Table 3: Results of application of model on new database

\begin{tabular}{ccccc}
\hline $\begin{array}{l}\text { Project } \\
\text { no. }\end{array}$ & $\begin{array}{c}\text { Construction } \\
\text { cost } \\
\text { [mil.eur] }\end{array}$ & $\begin{array}{c}\text { Actual time } \\
\mathbf{T}_{\mathbf{A}} \text { [days] }\end{array}$ & $\begin{array}{c}\text { Estimated time } \\
\text { model (6) } \\
\mathbf{T}=\mathbf{3 8 4}^{*} \mathbf{C}^{\mathbf{0 . 2 6 3}} \\
\text { [days] }\end{array}$ & $\begin{array}{c}\text { Estimated time } \\
\text { model (7) } \\
\mathbf{T}=\mathbf{3 6 8}^{*} \mathbf{C}^{\mathbf{0 . 2 9 5}} \\
\text { [days] }\end{array}$ \\
\hline $\mathbf{1 .}$ & 2,12 & 480 & 468 & 460 \\
$\mathbf{2 .}$ & 1,07 & 390 & 391 & 375 \\
$\mathbf{3 .}$ & 1,27 & 360 & 409 & 395 \\
$\mathbf{4 .}$ & 0,95 & 390 & 379 & 362 \\
$\mathbf{5 .}$ & 0,51 & 270 & 322 & 302 \\
$\mathbf{6 .}$ & 3,50 & 450 & 534 & 533 \\
$\mathbf{7 .}$ & 1,60 & 510 & 435 & 423 \\
$\mathbf{8 .}$ & 56,8 & 1230 & 1111 & 1212 \\
\hline
\end{tabular}

As already mentioned, the relationship between cost and time is defined by power function and this relationship is expressed by the constant $B$. The study was limited to analyzing only the effect of cost on construction time in the context of residential projects in Slovakia, providing all other variables constant.

\section{Conclusion}

After being confirmed many times in the world, it is able to point out that the credibility of Bromilow's time-cost model was proved also for Slovakia. This is just the first research of this kind and it only presents an introduction to further researches in defining models for rapid estimation of construction time. Obtained mathematical model is applicable only for residential projects in Slovakia. The study was limited to analyzing only the effect of cost on construction time in the context of residential projects in Slovakia, providing all other variables constant. For future studies, it will be useful to include other variables such as gross floor area or building volume, number of residences, shape of building, number of stories, and analyze their effect on total construction time.

\section{Acknowledgements}

The article presents a partial research result of project VEGA - 1/0677/14 "Research of construction efficiency improvement through MMC technologies". 
Paper is the result of the Project implementation: "University Science Park TECHNICOM for Innovation Applications Supported by Knowledge Technology", ITMS: 26220220182, supported by the Research \& Development Operational Programme funded by the ERDF.

\section{References}

[1] Ng, S.T., Mak, M., Skitmore R.M. \& Varnam M. (2001).The Predictive Ability of Bromilow's Time-Cost Model. Construction Management and Econonics. Vol. 19 (2), p. 165-173.

[2] Ameyaw, C., Mensah, S. \& Arthur, Y.D. (2012) Applicability of Bromilow's time-cost model on building projects in Ghana. In: Proc $4^{\text {th }}$ West Africa Environment Research Conference, Abuja, Nigeria, 2012, p.881-888.

[3] Choudhury, I. \& Rajan, S.S. (2004) Time-cost relationship for residential construction in Texas. Texas A\&M University.

[4] Ogunsemi, D.R. \& Jagboro, G.O. (2006) Time-cost model for building projects in Nigeria. Construction Management and Econonics. Vol. 24, p. 253-258.

[5] Tažiková, A. \& Kozlovská, M. (2013) Effect of the construction cost calculations to the sustainable development of buildings. In: Visnik Nacional'nogo universitetu L'vivska politechnika: Teorija i praktika budivnictva. No. 756 (2013), p. 298-303.

[6] Assefa, A. (2008) Time-cost relationship for public road construction projects, Addis Ababa University School of Graduate Studies.

[7] Žujo, V. \& Car-Pušić, D. (2009) Application of „time-cost“model in construction project management, Bosnia and Herzegovina. Web: http://bib.irb.hr/datoteka/444400.92-ujo-CarPui.pdf (19.2.2014).

[8] Kozlovská, M. \& Tažiková, A. (2012) Objektivizácia časových parametrov výstavby. Technická univerzita v Košiciach, Košice.

[9] Anděl, J. (2007) Statistické metódy. Matfyzpress, Praha, ISBN 80-7378-003-8.

[10] Kozlovská, M., Struková, Z. \& Tažiková, A. (2010) Access to construction time objectiveness In: Organisation, Technology and Management in Construction : An International Journal. Vol. 2, No. 2, p. 200-206.

[11] Kozlovská, M., Spišáková, M. \& Petrík, M. (2013) Potential for expansion of BIM technology in Slovakia In: Organization, Technology and Management in Construction : 11th International Conference: Proceedings: Dubrovnik, 28th - 30th September 2013. - Zagreb :University of Zagreb, 2013 p. 214-221. 